\title{
40S Ribosomal Protein S3
}

National Cancer Institute

\section{Source}

National Cancer Institute. 40S Ribosomal Protein S3. NCI Thesaurus. Code C29906.

$40 \mathrm{~S}$ ribosomal protein S3 (243 aa, $27 \mathrm{kDa}$ ) is encoded by the human RPS3 gene. This protein plays a role in translation and DNA repair. 